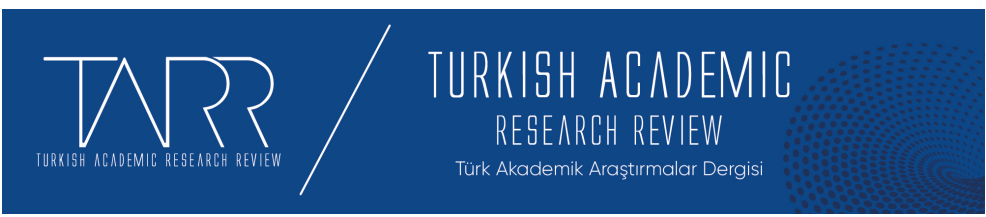

e-ISSN: 2602-2923

Yıl/Year: 2020 Cilt/Volume: 5 Sayı/Issue: 3

\title{
Psikanaliz Yanılgısı
}

The fallacy of psychoanalysis

Orhan Gürsu - Süreyya Nur Can

Doç. Dr., Akdeniz Üniversitesi, Din Psikolojisi ABD. E-posta: orhangursu1@gmail.com, Orcid:0000-0002-7478-371X

Yüksek Lisans Öğrencisi, Akdeniz Üniversitesi, Sosyal Bilimler Enstitüsü, Felsefe ve Din Bilimleri ABD., Antalya, E-posta: sureyyanur.can@gmail.com Orcid: 00000003-3795-3617

\begin{tabular}{r|l} 
Makale Bilgisi & Article Information \\
Makale Türü - Article Type & Kitap İncelemesi / Book Review \\
Geliş Tarihi - Date Received & 24 Temmuz / July 2020 \\
Kabul Tarihi - Date Accepted & 25 Eylül / September 2020 \\
Yayın Tarihi - Date Published & 30 Eylül / September 2020 \\
Yayın Sezonu & Temmuz - Ağustos - Eylül \\
Pub Date Season & July - August - September
\end{tabular}

Atıf / Cite as: Gürsu, Orhan-Can, Süreyya Nur, Psikanaliz Yanılgıs1/ The fallacy of psychoanalysis. tarr: Turkish Academic Research Review, 5 (3), 461-464. doi: tarr.773520.

Intihal / Plagiarism: Bu makale, en az iki hakem tarafından incelenmiş ve intihal içermediği teyit edilmiştir. / This article has been reviewed by at least two referees and confirmed to include no plagiarism. https://dergipark.org.tr/tr/pub/tarr

Copyright (C) Published by Mehmet ŞAHIN Since 2016- Akdeniz University, Faculty of Theology, Antalya, 07058 Turkey. All rights reserved.

Turkish Academic Research Review - Türk Akademik Araştırmalar Dergisi https://dergipark.org.tr/tr/pub/tarr 


\title{
Psikanaliz Yanılgısı
}

\author{
The fallacy of psychoanalysis
}

\section{Orhan Gürsu - Süreyya Nur Can}

Prof. Dr. M. Kerem Doksat

Psikanaliz Yanılgısı

Ankara 2014, Alter Yayıncılık, 1. Basım, 174 s., ISNB 978-605-4922-88-8

Tıp Fakültesinden mezun olduktan sonra ihtisasını Psikiyatri alanında sürdürmüş olan M. Kerem Doksat 'Evrimsel Psikiyatri'yi Türkiye'ye tanıtan kişi olmuştur. İçerisinde bazı makalelerinin de bulunduğu Psikanaliz Yanılgısı adlı eserini 2014 yılında okuyucularına sunan Doksat, 174 sayfadan oluşan kitabında herhangi bir bölümlendirmeye ihtiyaç duymamıştır. Kitapta din kavramından evrime (s.17-58), Psikanalizi öğrenmek için gereken maliyet ve süreye (s.58-59); Sigmund Freud, Wilhelm Reich, Melanie Klein gibi Psikanaliz tarihinin önemli isimlerine, bu isimlerin kișisel hayatları, teorileri ve vakalarına (s.64-131), "Psikanalizin" ne olduğuna (s.132-159) kadar pek çok konuya yer vermiştir. Psikanalizin, hastalarını tedavi etmediği gibi aksine onlara daha çok zarar verdiğini ve artık bir yeniçağ dini olduğunu iddia eden Doksat; Psikanaliz Yanılgısı adlı eserini, bu iddiasındaki gerekçeleri açığa çıkarmak için kaleme aldığını dile getirmiştir. İçeriğiyle uyumlu bir ironiyi yansıtması açısından kitabın adı gibi kapağı da dikkat çekmektedir: Bir "Psikanalist Divanı'na" uzanmış ve sadece kemikleri kalmış insan ve Psikanalist olarak da Freud resmedilmiştir.

Batı kültüründe yaşanan tarihi gelişmelere paralel olarak, Rönesans ve reform hareketleri gibi, psikolojide de dinsel olandan uzaklaşma ve sekülerleşme şeklinde, gelişmeler ve değişmeler meydana gelmiştir. 'Aydınlanma Hareketi' olarak adlandırılan bu yenilikleri, Hristiyanlığın çöküşüyle oluşan bir boşluk ve bu boşluğu doldurmaya yarayacak, Psikanaliz gibi, alternatif kurumlara ve Nietzsche, Marx ve Freud gibi, kuruculara olan ihtiyaç takip etmiştir (Merter, 2016: 15-33). Psikanaliz Yanılgısı'n'da Batı kültürünün, bu gelişmelerle beraber dini, manevi unsurlarını kaybedip yeni dinler oluşturduğundan ve bunların da din değil tedavi olarak adlandırıldığından bahsedilerek Psikanalizin artık bir din statüsünde olduğu iddia edilmiştir. Dinsel baskıdan kurtulan her şeyi bilimsel bir zeminde toplama çabası, dinsel olanın yerini doldurmaya yarayacak yeni, farklı ve sarsıcı öyküler, senaryolar, organizasyonlar, paradigmalara olan ihtiyacı ortaya çıkmıştır. Psikoloji alanında Freud'un kuramı olarak Psikanalizin hem klasik dinler kadar iddia ve vaatleri içinde barındırması hem de kendisini takip eden müritleri bulunmasıyla bir dinden pek farkı kalmamıştır (s.17-58). Bu iddiayı ispatlamak amacıyla Doksat kitabının ilk bölümlerinde din konusunda uzunca bilgiler verip daha sonra Psikanalizin bu kavrama nasıl uyduğu açıklamıştır. Yazarın bu konudaki şu cümlesi dikkate değerdir: "Tanrı ölmüştü, çünkü Psikanaliz vardı" (s.56). Nitekim Böyle Buyurdu Zerdüşt eserinde Nietzsche de "Tanrı öldü: şimdi biz istiyoruz ki, üstinsan yaşasın." diyerek aynı noktaya dikkat çekmektedir (Nietzsche, 2007: 388). Dinin sadece bir dogma olarak görüldüğü ve etkisinin giderek azaldığ 1 bir dönemde onun

Turkish Academic Research Review - Türk Akademik Araştırmalar Dergisi 
boşluğunu dolduracak bir şeyler ve birileri gerekmiştir. Yazarın düşüncesiyle paralel olarak, bir dönem psikanalistler "Tanrısız yüzyılın papazları" olarak anılmıştır (Haque, 2012: 149).

Kitabı önemli kılan bir nokta da dokunulmamış ya da göz ardı edilmiş bir durum olan Psikanalizin hem uygulayıcı için hem de hasta için maliyeti ve süresi konusudur. Yazar, klasik Psikanaliz uygulamasının yaklaşık 3,5 yıl; eğitiminin ise 4 ile 10 yıl arasında sürdüğünü ve bunun ilaç endüstrisindeki ranttan pek de farklı olmadığını dile getirmiştir (s.58). Yazarın bu konudaki görüşleriyle bağlantılı olarak, orta gelirli bir ailenin dahi haftalık olarak ve bu kadar uzun süre tedaviye devam etmeye maddi durumunun yetmeyeceği gerçeği düşünüldüğünde, akıllara Psikanalizin toplumun hangi kesimine hitap ettiği sorusu gelmektedir. Bununla beraber kitapta bir terapist seçiminde aslında terapistin aldığı eğitimlerin değil, terapistin hastaya ne kadar uygun olduğunun önemli olduğundan bahsedilmektedir. $\mathrm{Bu}$ konu din psikolojisi alanındaki tartışmalarda da çok sık gündeme gelmektedir. Peki dini, manevi hassasiyeti olan bireylere materyalist ya da seküler bir yaklaşımla müdahalede bulunmak ne kadar fayda sağlayabilir? Burada önemli olan terapistin aldığı eğitim mi yoksa, danışana olan uygunluğu mudur? Bu konu özelde Psikanaliz için de sorulması gereken bir sorudur. Psikanaliz her hastaya, her kültüre ve her konuya hem kuramsal açıdan hem de uygulamaları açısından hitap etmekte yeterli midir? İstisnaları yok mudur?

Doksat'ın en önemli iddialarından biri ise Psikanaliz yönteminin hiçbir hastayı tedavi etmediğine dair görüşüdür. Yazar bu iddiasını birkaç yerde şu şekilde dile getirmiştir: "Psikanalitik yöntemlerle iyileşen, salah veya şifa bulan hemen hiçbir gerçek hasta yoktur" (s.63). "Ben de Psikanalizle iyileşen hiçbir hasta görmedim ama yapıldıktan sonra darmadağın olan pek çok kişiyi üzülerek müşahede ettim" (s.134). Yazar bu görüşlerini Küçük Hans, Dora, İsmi Meçhul Bir Kız, Kurt Adam ve Sıçan Adam gibi başlıklarda bahsettiği Freud'un hastalarının iyileşmediği iddiası üzerinden desteklemeye çalışmıştır. Yazarın iddialarıyla benzer şekilde Göze (1992: 23), Freud'un kendi eserlerindeki kişisel çatışmalarından yola çıkarak, Psikanaliz ile kendini dahi başarıyla tedavi edemediğini belirtmektedir. Unutulmamalıdır ki Psikanaliz de dâhil olmak üzere "Modern psikolojinin verileri kendi evrensellik iddialarına karşın Batı bilim paradigmasının ürünüdür." (Şahin, 2019: 36). Yanlışlanabilir olmayan hiçbir şeyin bilim olmayacağını söyleyen Doksat, Psikanalizin içinde bulunduğu durum gereği bilimsellikten uzak olduğunu savunmaktadır. Çünkü "Theoria hakikatin ta kendisi olup çıkmıştı" (s.56). Ayrıca Psikanalizin herkesi ve her şeyi tedavi edebilme iddiasına karşılık, her şeyi yapan ve herkese uygun olan, yani omnipotant (tam güç, kadir-i mutlak) olan, bir teorinin mümkün olamayacağını vurgulamaktadır. Bu iddiasıyla Psikanaliz Yanılgısı, üzerinde pek düşünülmemiş ve sorgulanmamış noktalara parmak basması açısından önemlidir.

Psikanaliz Müslüman coğrafyalarda genelde ihmal edilen ve küçük görülen bir yaklaşımla karşılanmaktadır (Ahmed \& Amer, 2013: 91). Psikanalizin psikolojiye sadece bilinçdışı kavramını kazandırması (Merter, 2016: 76) ve alandaki gelişmelere öncü olması göz ardı edilemeyecek durumlardır. Fakat ortaya konulan teori ve kavramlarının bilimselliği, Odipus kompleksi gibi, terapilerin yararına dair ölçüt, Freud ve diğer öncülerinin uygulamalarındaki sorunsallar, pek çok kaynakta eleştiri konusu olmuştur. Mesela Thomas Szasz (2012: 164), Freud'un Odipus kompleksinin evrenselliğini bilimsel bir zeminde değil mitolojiyi kendi teorisini destekleyecek şekilde yorumlayarak ispatlamaya çalıştı̆̆ından bahsetmektedir. Hatta daha da ileriye giderek mitolojik bir karakter olan Odipus'dan yola çıkarak bir kompleks oluşturmasının Freud'un retorik becerisinden kaynaklandığını dile getirmiştir (Szasz, 2012: 183). Psikanaliz Yanılgısı da bu konularda okuyucularını

Turkish Academic Research Review - Türk Akademik Araştırmalar Dergisi 
haklı bir sorgulamaya götürmektedir. Doksat Freud, Reich ve Klein'in vakalarından, günümüz Psikanaliz uygulayıcılarının tavırlarına ve yaklaşımlarına kadar pek çok konuya değinerek Psikanalizin eleştirilemez, mutlak kabul edilen, en iyi terapi şekli, bilimsel bir çalışmanın sonucu olması gibi tabularını yıkacak gerekçeleri ortaya koymaya çalışmıştır. Kitapta günümüzde Psikanaliz alanında çalışan bazı isimlere ve bu isimlerle Psikanalizi konuşmaya yönelik girişimlerde karşılaştığı tavırlara da yer veren Doksat, Psikanalizin tartışılamaz olmasına karşı çıkmıştır. Okuyucu, kitapta baştan sona bu düşüncesin farklı açılardan irdelenmesine şahitlik etmektedir.

Sonuç olarak M. Kerem Doksat'ın Psikanaliz Yanılgısı eserinin başlığı, kapak resmi, arka kapak yazısı ve yazılış amacı ve içeriği ile dikkat çekici olduğu düşünülmektedir. Kitabı okuyanların Psikanalizle ilgili sorgulamalarını, bu konuya daha farklı açılardan bakma ve daha detaylı araştırma eğilimlerini artması beklenmektedir. $\mathrm{Bu}$ bağlamda özellikle alana yeni girmiş kişiler için bir çırpıda, akıcı bir şekilde okunabilecek bir kitap olduğu düşünülmektedir.

\section{Kaynakça}

Ahmed, S., \& Amer, MM (Eds). (2013). Müslümanlar İçin Psikolojik Danışmanlı: Kültüre ve Dine Duyarlı Ruh Sağlı̆̆ı Müdahaleleri. (1. Baskı). Nobel Yayınevi.

Doksat, K. (2014). Psikanaliz Yanılgısı. Ankara: Alter Yayıncılık.

Göze, E. (1992). Fröyd ve Fröydizmin İçyüzü. İstanbul: Boğaziçi Yayınları.

Haque, A. (2012). Psikoloji ve Dinin Etkileşimi: Trendler ve Gelişmeler. Ankara Üniversitesi İlahiyat Fakültesi Dergisi, 53(1), 149-166.

Katipoğlu, B. (1991). Din Psikolojisi Açısından Freud Psikanalizi ve Din. İzmir: Özden Ofset. Yayınlar1.

Merter, M. (2016). Dokuz Yüz Katlı Insan (15. Bask1). İstanbul: Kaknüs

Murdock, N. L. (2018). Psikolojik Danışma ve Psikoterapi Kuramları. F. Akkoyun, (Çev. Edt.), (2.Basım) Ankara: Nobel Yayınevi.

Nietzsche, F. (2007). Işste Böyle Dedi Zerdüsşt. İstanbul: Kabalcı Yayınları.

Szasz, T. (2012). Psikoterapi Miti. İstanbul: Goa Yayıncılık.

Şahin, Z. A. (2019). Müslüman Psikologlar Kertenkele Deliğinden Çıktı Mı? İslami Psikoloji Alanındaki Gelişmeler. Turkish Studies, 14(2), 15-47.

Turkish Academic Research Review - Türk Akademik Araştırmalar Dergisi 